\title{
Enron/Off: \\ A Morality Play In Three Acts
}

Heidemarie Lundblad, (E-mail: heidemarie.lundblad@csun.edu) California State University Northridge Naomi Berger Davidson, (E-mail: naomi.berger.davidson@csun.edu), California State University Northridge

\begin{abstract}
The Enron collapse has many facets. It is particularly rich in financial reporting and disclosure issues. This case addresses some of Enron's creative revenue recognition practices and the role Special Purpose Entities and derivatives played in Enron's reported success and ultimate failure. The role of Enron's board of directors and senior management is also covered. The case is designed for use in intermediate and advanced accounting and management courses. It includes some suggested instructional questions.
\end{abstract}

\section{Prologue}

"You know what the difference is between the state of California and the Titanic? At least when the Titanic went down, the lights were on." (Jeffrey Skilling, former CEO of Enron June $12,2001)^{1}$

On August 14, 2001 Mr. Skilling resigned from Enron; on November 8, 2001 Enron restated its earnings for the years 1997 through 2000; on November 30, 2001 Enron filed for bankruptcy protection. What about California? The lights are on; its energy crisis appears to have disappeared; and, by a peculiar twist of fate, California may have been the snowball that triggered the Enron avalanche.

What happened? Until its spectacular collapse in late 2001, Enron was hailed as one of the most innovative companies in the U.S., if not in the world. Its management was celebrated in business publications and on talk shows for creating new business models.

Kenneth Lay (previously known as "Kenny Boy" by former Texas governor, now US President George W. Bush) founded Enron Corporation in 1985 by merging two small Texas pipeline companies. From this modest beginning the company grew rapidly into one of the largest energy traders in the world. It handled about one quarter of the nation's traded-electricity and natural-gas transactions, with reported revenues exceeding $\$ 150$ billion and assets of more than $\$ 60$ billion. (Asian WSJ, Oct.26, 2001, p. M6) By 2000, Enron was considered the seventh largest company in the US. (Sloan, 2002) In the process the pipeline company "morphed into a bank that was a dot.com" (Elliot, 2001), it has since filed the largest bankruptcy case in US history. By the end of January, 2002, Enron had earned the dubious distinction of driving the 'war against terrorism' below the fold of major newspapers: according to a Los Angeles Times headline (1/27/02) "Enron Debacle Shakes Up Congress' Agenda; War Now Shares Spotlight".

While it is too early for a complete assessment of the Enron debacle, one major victim is Enron's auditor, Andersen LLP, formerly one of the "Big Five" accounting firms. The accounting industry in general has come under attack for its failure to detect or challenge questionable reporting practices and for providing not only auditing but also consulting services to its clients.

\footnotetext{
${ }^{1}$ Mr. Skilling's made this joke at the Strategic Directions Technology conference in response to a question about California's energy crisis. Source: (Eichenwald and Henriques, 2002)
} 
The ramifications of Enron's collapse extend beyond U.S. borders. The company owned power generating and trading companies in many parts of the world, ranging from India to Poland. Financial reporting practices not only in the U.S., but internationally have come under intense scrutiny: The role of the Financial Accounting Standards Board and the accounting standard setting process are being questioned. According to Sir David Tweedie, Chairman of the International Accounting Standards Board (IASB):

Enron was a salutary shock to the Americans -- who have a complicated rules-based approach to setting accounting standards -- that might make them more eager to converge with the IASB's principle-based approach to accounting standards. (AccountancyMagazine.com, 2001)

Enron was a pioneer (and tireless promoter) of energy deregulation and became a major force in the trading of energy contracts in the U.S. and overseas markets. In addition, Enron extended its business to a variety of fields, such as water, broadband communication, and other technology ventures. ${ }^{2}$ It was widely considered one of the flagship companies of the "New" economy. However, in retrospect it appears that Enron's success was not entirely due to the brilliant business strategies developed by Lay and former Chief Executive Officer Skilling. As the unraveling scandal shows, a significant portion was attributable to creative financing and accounting strategies. The Enron debacle has many facets. This case is limited to financial reporting and ethical considerations.

\section{Enron's Corporate Culture And Values}

In many ways Enron resembled the dot-com companies. "The company was housed in a spiffy 50 -story building in downtown Houston, a structure whose elevators flashed Enron's latest stock price and delivered upbeat messages to get employees energized by the time they got to their offices. In the best New Economy tradition, Enron had an on-site health club, casual dress code and employees who piled up paper wealth by investing in Enron stock. (Sloan, 2001, p.48) "Enron wasn't just a business, it was a lifestyle that rewarded foam-mouthed aggression" (Sloan 2002, p. 21). The company was seen as an extremely attractive employer: Enron was hailed as "one of America's most admired companies, and a perennial favorite on "best places to work" lists" (Sloan 2002, p.19). Management and employees apparently believed Enron's slogan, "Endless possibilities."

Along with this slogan, Enron created Our Values. They are:

Communication -- We have an obligation to communicate. Here, we take the time to talk with one another... and to listen. We believe that information is meant to move and that information moves people.

Respect -- We treat others as we would like to be treated ourselves. We do not tolerate abusive or disrespectful treatment.

Integrity -- We work with customers and prospects openly, honestly and sincerely. When we say we will do something, we will do it; when we say we cannot or will not do something, then we won't do it.

Excellence -- We are satisfied with nothing less than the very best in everything we do. We will continue to raise the bar for everyone. The great fun here will be for all of us to discover just how good we can really be. (Enron Annual Report 2000, p. 53)

Enron management was tireless in promoting the company's "special character" and "decided...that it could "financialize" almost anything" (Sloan 2002, p. 21). Consequently, it did not hesitate to disregard the principles embodied in the Value Statement to create the impression of a thriving organization. For example, to

\footnotetext{
${ }^{2}$ In its last $\left(3^{\text {rd }}\right.$ quarter, 2001) quarterly report Enron identified its broadband and global investments at $\$ 8$ billion. It further stated that these investments have not been profitable. (Form 10 Q, p. 10)
} 
impress financial analysts, management moved a large number of employees to an unused trading room and ordered them to pretend to be furiously trading energy contracts.

But to achieve Enron's goal of becoming "the world's greatest company" (Eichenwald and Henriques, 2002) required more than charades: It required a continuous infusion of cash. This in turn necessitated favorable debt/equity ratios and high stock prices. Enron's balance sheet was not "large enough" to support the company's extraordinarily rapid growth. It appeared essential to management to keep as much debt as possible off Enron's balance sheet. Consequently, Enron developed an increasingly complex financial structure under the leadership of its former chief financial officer (CFO) Andrew Fastow. Important components were creative equity securities such as Monthly Income Preferred Shares and Special Purpose Entities.

\section{Monthly Income Preferred Shares (MIPS)}

Enron did not invent MIPS, this honor belongs to Goldman Sachs (McKinnon and Hitt, 2002); however, MIPS became an important part in Enron's financial toolkit. In 1993 Enron issued \$214 million of preferred shares (the MIPS) through Enron Capital LLC (a financial subsidiary incorporated in Turks and Caicos, a Caribbean tax haven). The MIPS promised $8 \%$ annual dividends, payable in monthly installments. Enron Capital LLC then loaned the proceeds to the parent company in exchange for a note payable over 50 years. MIPS enabled Enron to do the following: It was able to deduct \$24 million interest expense from its US taxes in 1993 and 1994; however, on its balance sheet the securities were listed as "preferred stock in subsidiary companies." MIPS were not the only creative use of equity instruments. Enron also discovered that it could improve its balance sheet and income statement by transferring its stock to some of its "Special Purpose Entities (SPE). For example, it issued stock in the amount of $\$ 1$ billion in exchange for notes receivable to three SPEs, as is discussed in the following sections.

\section{Partnerships and Special Purpose Entities (SPEs): Braveheart; JEDIs and Chewco; and the Raptors}

SPEs and a bewildering network of partnerships were an important element of Enron's "business model". They enabled the company to engage in a variety of actions that helped maintain the company's image of success. Enron used over three thousand partnerships ${ }^{3}$. However, Braveheart; JEDIs and Chewco; and the Raptors suffice to illustrate their role in Enron's apparent success and ultimate failure.

\subsection{ACT I - Braveheart (The Enron Version):}

\section{Cast of characters:}

Enron:

Entered into a partnership with Blockbuster to develop a market for on-line video rentals.

Portland General Electric (PGE): A subsidiary of Enron. It had a fiber optic network, but needed customers. Blockbuster: $\quad$ A major video rental company.

nCube: Oracle founder Jim Ellison's private technology company. nCube provided equipment and \$2 million to the partnership.

CIBC World Markets: Braveheart: Investment banking division of Canadian Imperial Bank of Commerce. An SPE owned by Enron and CIBC. It generated revenue or did it?

Energy trading was Enron's core business; but the company expanded rapidly into other, unrelated areas, such as fiber optics and broadband. In 1998, Enron acquired PGE an Oregon utility with a fiber optics network. Enron expected the market for broadband services (for the transmission of business and residential data) to grow rapidly and consequently expanded PGE's small network aggressively. Unfortunately, demand for broadband did not grow as quickly as anticipated and Enron searched for something to utilize its capacity. Movie rentals via broadband connections seemed a promising solution.

\footnotetext{
${ }^{3}$ Enron's Form 10-K for 2000 contains sixty pages listing approximately 3000 subsidiaries and limited partnerships worldwide.
} 
In July of 2000 Enron entered into a partnership with Blockbuster to develop a new type of movie rental business. As envisioned by enthusiastic Blockbuster and Enron executives, customers would order and download movies using a TV set-top box, utilizing Enron's fiber-optic telecommunications network. The project developed slowly: At its peak, in March of 2001, the pilot project counted only 1,000 households (mainly non-paying customers) in four cities. Shortly thereafter the partnership between Enron and Blockbuster was terminated, apparently due to technological problems.

Although the partnership lasted only a short time, it nevertheless provided Enron with an important revenue source in 2000 and for the first quarter of 2001, through the magic of operation Braveheart.

While Blockbuster treated the venture as a pilot project and recognized no revenue from it, Enron decided to "monetize" it through a second partnership (Braveheart) with CIBC World Markets. CIBC paid \$115.2 million in exchange for the right to $93 \%$ of Braveheart's cash flow for ten years. To make the investment more enticing, Enron promised to repay the full value of the investment if the project failed to be profitable. (Smith, 2002)

Once it obtained the CIBC cash infusion, Enron recognized $\$ 110.9$ million profit for the $4^{\text {th }}$ quarter of 2000 and the $1^{\text {st }}$ quarter of 2001. This sharply reduced the losses Enron had to recognize from the fiber-optics division.

CIBC is now trying to determine if there is any chance of repayment of its $\$ 115$ million; nCube has written off its investment; and in the $3^{\text {rd }}$ quarter of 2001 Enron's reversal of the incorrectly recognized revenue contributed to the $\$ 618$ million loss reported in Enron's final quarterly financial statement. (Enron, Form 10Q, 2001)

\subsection{ACT II - Star Wars (The Enron Version): \\ Executive Producer: Andrew Fastow, Director: Michael Kopper}

\section{Cast of Characters:}

CALPERS: $\quad$ The California State Retirement System - It made money on the JEDIs, but ended up losing

\section{JEDI 1 and 2:} \$45 million on Enron stock.

Chewco: they trigger the avalanche that buried Enron?

Barclays: Named after Chewbacca, an SPE used to pay $\$ 382$ million to CALPERS without affecting Enron's balance sheet.

Bank that loaned $\$ 240$ million to Chewco (guaranteed by Enron); it also loaned money to the Fastow (later Kopper/Dobson) owned companies to provide the "outside" $3 \%$ investment in Chewco.

Andrew Fastow: Enron's Chief Financial Officer; he created the structure and initially owned the "outside" LLC's (SONR1 and 2); later sold them to Michael Kopper.

Michael Kopper: An Enron director. He managed Chewco and reported to Andrew Fastow, later he transferred his investments in SONR2, Big and Little River to William Dobson.

William Dobson: Also appearing: Kopper's domestic partner, he did not work for Enron. SONR2, Big River and Little River - Specially created companies used to contribute the "outside" investment to Chewco.

In 1993 Enron entered into a partnership with CALPERS to invest in power plants and similar items. CALPERS invested \$250 million cash and Enron contributed stock valued at \$250 million in JEDI1: The investment proved quite successful, in 1997 Enron therefore suggested a second partnership with CALPERS- JEDI2, with investments of $\$ 500$ million from each partner. While CALPERS was willing, it insisted on first cashing out its stake in JEDI1, which had grown to $\$ 383$ million. To generate the cash, Enron formed a new partnership: Chewco, consisting of Enron executives and some outside investors (See Exhibit 1). Enron loaned Chewco \$132 million and guaranteed $\$ 240$ million in loans taken out by Chewco. An additional $\$ 11.5$ million was to be contributed by outside investors, thus qualifying JEDI 2 as a "special purpose entity" that would not have to be consolidated. 
Unfortunately, the outside investors only contributed about half of that amount. Chewco had to borrow the remainder with collateral provided by Enron. A majority of the funding was provided through loans to "Big River" and "Little River", two "Funding" companies owned by Kopper (later Dobson). Barclays loaned \$11.1 million and $\$ 331,000$ respectively to them. However, Barclays required that reserve accounts in these amounts be maintained at Barclays.

\section{Revenue recognition from Chewco and JEDI}

Chewco was set up primarily to keep debt off Enron's balance sheet, but it also generated revenue for Enron : Since Enron guaranteed the loan from Barclay's bank, it charged a loan guarantee fee. However, this fee was classified as a structuring fee of $\$ 17.4$ million of which $\$ 10$ million was recognized immediately (in 1997), with the remainder recognized in early 1998. Chewco used cash distributions from JEDI to pay the fee.

Exhibit 1: Enron and Chewco

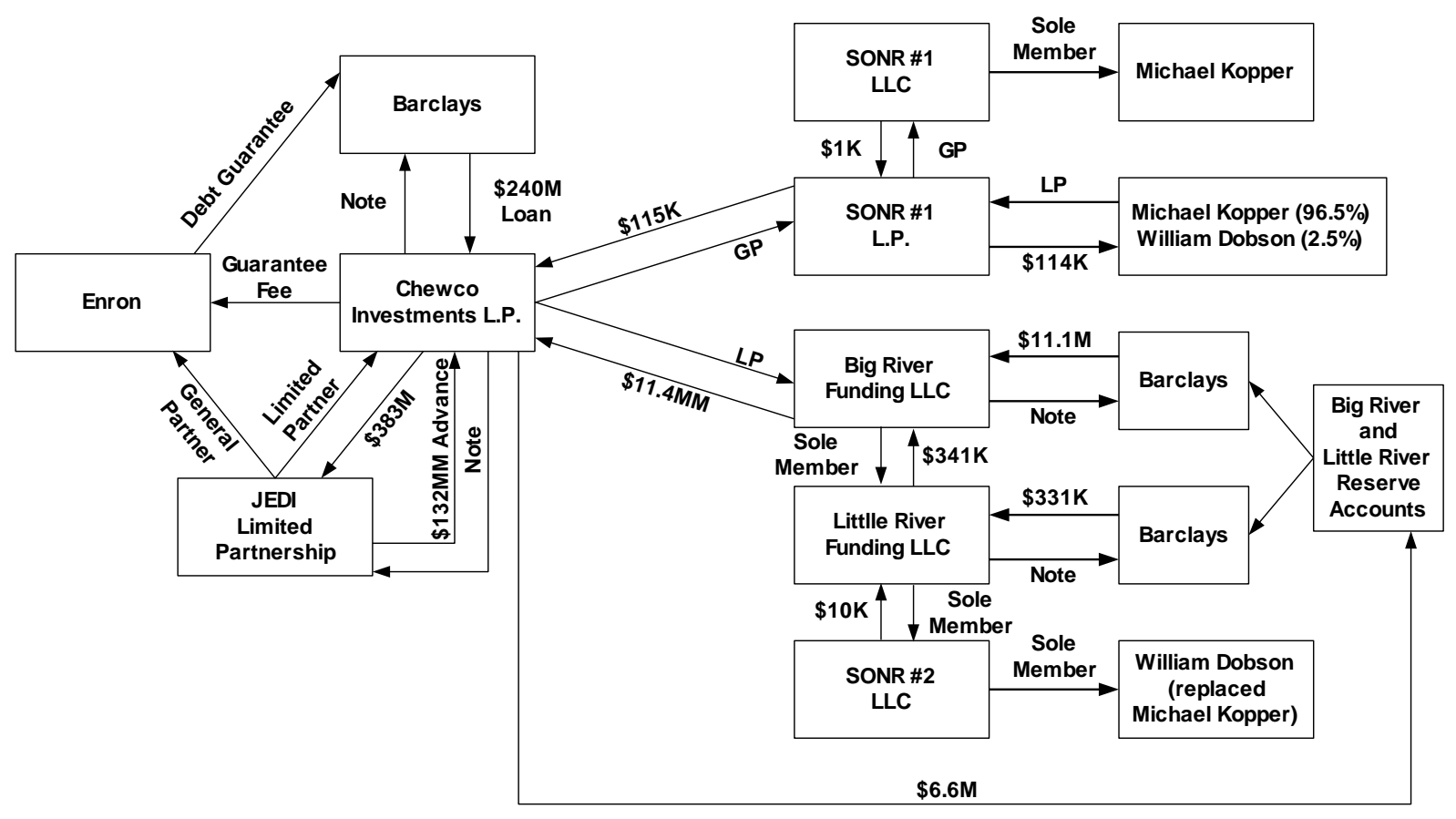

Legend: LLC: Limited liability company

LP: Limited Partnership

Source: Report of the Special Investigative Committee of the Board of Directors of Enron Corp. (Powers) p. 51

JEDI was an Investment Fund, and thus carried its assets at fair value ("marked to market"). Enron's contribution to JEDI consisted of Enron stock. JEDI treated the Enron stock as part of its 'merchant portfolio" ${ }^{4}$ and recognized the increases in its value as part of current income. Enron recognized income from JEDI on the equity basis and, therefore, it recognized $\$ 126$ million in income (from the appreciation of Enron stock) in the $1^{\text {st }}$ quarter of 2000. In the $1^{\text {st }}$ quarter of 2001 , the decline in the stock's value required recognition of a loss of $\$ 94$ million.

\footnotetext{
${ }^{4}$ Investments in the "merchant portfolio" are known as "trading securities" for accounting purposes
} 
A final revenue source from JEDI was a management fee. The original 1997 partnership agreement provided for an annual management fee of the greater of $2.5 \%$ of $\$ 383$ million or $\$ 2$ million. The fee was payable through 2003. In 1998, this was reclassified and termed a "required payment" to Enron. The apparent purpose was to permit Enron to recognize revenue immediately. Subsequently, Enron recognized the present value of these payments ( $\$ 28$ million less $\$ 2.5$ million of reserves) as revenue for the $1^{\text {st }}$ quarter of 1998 .

\subsection{ACT III - Jurassic Park (The Enron Version) \\ Director and Executive Producer: Andrew Fastow}

\section{Cast of Characters:}

LJM1 and 2:

The Fastow Family Foundation:

Big Doe:

LJM Swap Sub LP:

Michael Kopper, William Dobson: Reprised the roles they originated in Braveheart.

The Raptors:

I: Talon;

II: Timberwolf;

III: Pronghorn and Porcupine;

IV: Bobcat. They were supposed to hedge a number of Enron investments but did they?

Also appearing:

Ben Glisan: Kristina Mordaunt; Kathy Lynn; Ann Yeager Patel: Enron employees who also worked for LJM2. Each contributed $\$ 5,800$ (or less) and received up to $\$ 1$ million shortly thereafter.

Andrew Fastow, with the approval of Enron's board, created the "Raptor" SPEs for the ostensible purpose of hedging a variety of Enron investments and to purchase certain Enron assets. The actual structure of the raptors was extremely complex; the following discussion provides a streamlined description. ${ }^{5}$

\section{Creation and Purpose of the Raptors and Swap Sub}

In 1999, LJM Swap Sub L.P. (Swap Sub) was the first SPE created in connection with the LJM partnerships. Its primary purpose was to hedge Enron's investment in Rhythms NetConnections (Rhythms) and to help Enron recognize the increase in the market value of Enron stock.

The required 3\% outside investment was obtained as follows: Fastow, the general partner contributed $\$ 1$ million and two limited partners, financial institutions, invested \$15 million.

Enron supplied employees who conducted LJM's business with Enron. Although LJM was supposed to pay for these services, according to the Powers report it is doubtful that LJM paid anything. (Powers, p. 75)

\section{Capitalization of LJM1 and Swap Sub}

To obtain stock for employee stock option purchases Enron had entered into forward contracts to purchase Enron stock at a fixed price. As a result of the increase in Enron stock prices during 1999, these contracts had become quite valuable. In 1999 Enron restructured the forward contracts and transferred 3.4 million shares (market value $\$ 276$ million) of Enron stock to LJM1 and received a note receivable for $\$ 64$ million. ${ }^{6}$ While a significant

\footnotetext{
${ }^{5}$ For a more detailed description of the raptors see the "Report of Investigation of the Special Investigative Committee of the Board of Directors of Enron Corp.", hereafter referred to as “Powers", pages 68 to 147. ${ }^{6}$ Since most of the stock was restricted, it was discounted by about $\$ 108$ million.
} 
portion of the stock was restricted (could not be sold for four years), LJM1 was able to sell some of the stock for $\$ 3.75$ million. This amount and 1.6 million shares of the restricted Enron stock were then transferred to Swap Sub. Swap Sub could now be used to hedge Enron's investment in Rhythms.

Enron had acquired 5.4 million shares at $\$ 1.85$ per share in Rhythms, a privately held Internet provider that went public at \$21 a share in April of 1999. By May 1999 Enron's investment had a market value of \$300 million. The investment was held in Enron's merchant portfolio; consequently, Enron recognized increases (and decreases) in market value as part of its income. Based on the total acquisition price of $\$ 10$ million, Rhythms contributed $\$ 290$ million to Enron income in 1999. Enron was concerned about the effects on income due to possible fluctuations in the value of the investment, especially since Enron could not sell the stock prior to the end of 1999 . $^{7}$

Exhibit 2: LJM and Swap Sub

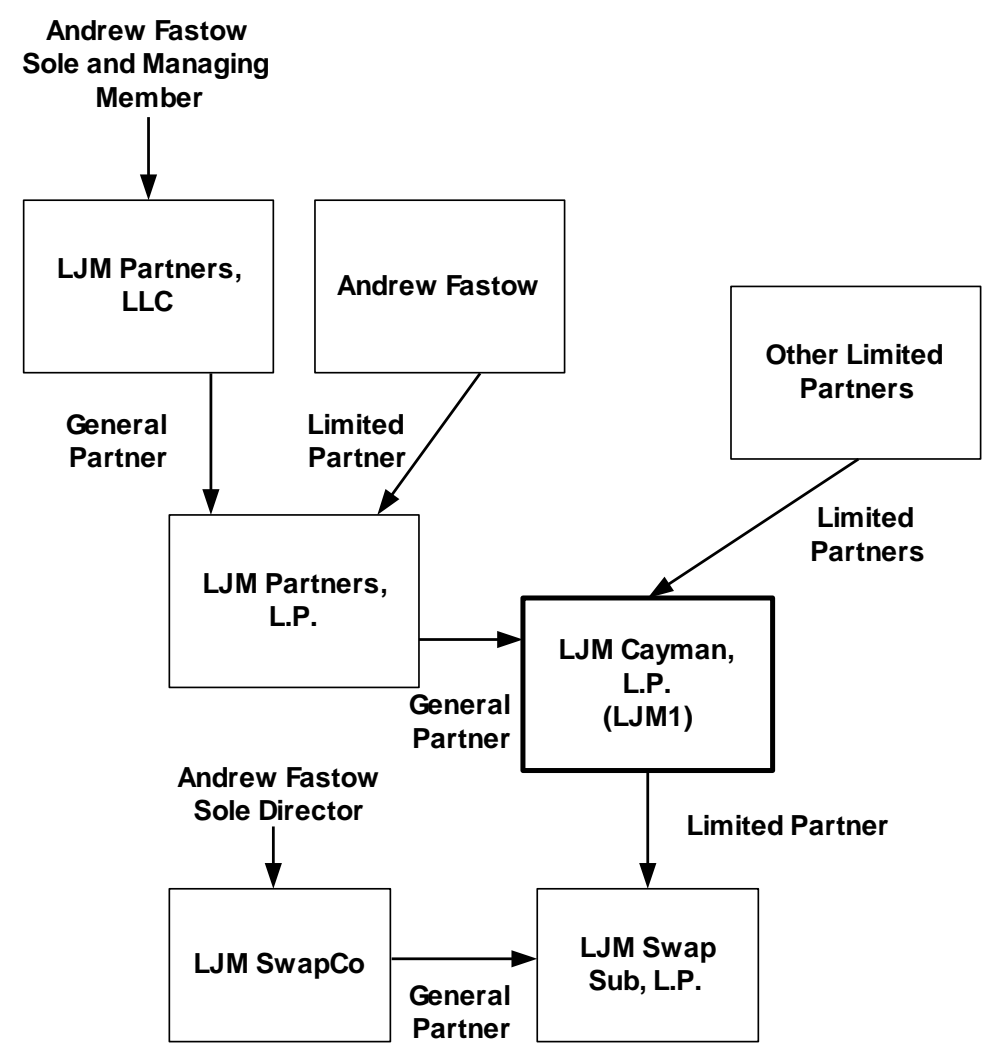

Source: Powers p. 70

Enron received a put option from Swap Sub for the Rhythms stock at $\$ 56$ a share in June 2004. The put option was valued at $\$ 104$ million. Enron (with the concurrence of Andersen LLP, its auditors) treated Swap Sub as an unconsolidated SPE. The transaction with Swap Sub appeared to enable Enron not only to isolate its financial statements from the effects of possible declines in Rhythms value, but also to recognize the increase in the value of the forward contracts. However, at the time Swap Sub apparently had negative equity: Its assets amounted to \$ 3.75

\footnotetext{
${ }^{7}$ In view of the fact that Rhythms NetConnections went bankrupt, this was a reasonable concern.
} 
million in cash plus Enron stock with a market value of approximately $\$ 80$ million, compared to the put option liability of $\$ 104$ million.

Subsequently, in July 2000, Enron and Swap Sub entered into four additional derivative transactions to improve the hedge.

It appeared that Enron had successfully hedged its investment in Rhythms: Even if Rhythms stock value declined, the \$300 million market value (and recognized income) was protected through the put option from Swap Sub. Or was it? By early 2000 the Rhythms stock was no longer restricted, its value continued to decline and it was likely that Swap Sub would default on its obligation under the put option. Enron decided to unwind the transaction: Under the terms of the unwind agreement Swap Sub returned the Enron stock (3.1 million post-split shares) and received $\$ 16.7$ million. It also retained the 3.75 million dollars it had received as part of the original capitalization. Since prior to the unwind Enron had loaned Swap Sub \$10 million, the total return to LJM1 was \$30 million.

In addition to Fastow and the two financial institutions who were the original general and limited partners involved, several other Enron employees also benefited from the unwind. Concurrent with the unwind agreement, Glisan, Mordaunt, Lynn, Patel and an LJM1 employee were approached by Kopper and agreed to invest in a partnership that together with the Fastow Family Foundation (FFF) and Big Doe (an LP controlled by Kopper) to acquire the interest of one of the limited partners in LJM1. The total investment in this partnership amounted to \$70,000: \$25,000 each from FFF and Big Doe, \$5,800 each from Glisan and Mordaunt, smaller amounts from the others. FFF received $\$ 4.5$ million on May 1, Glisan and Mordaunt received $\$ 1$ million. At the time Fastow, Kopper, Glisan, Mordaunt, Lynn and Patel were employed by Enron and were involved in the LJM2 transactions. (Powers p. 95)

In October 1999, Fastow with the agreement of Enron's board created LJM2 for the purpose of enabling Enron to "syndicate its capital investments in order to grow" (Powers, p. 71). LJM2 was significantly larger than LJM1: eventually, it had approximately 50 limited partners who committed \$394 million (Enron Form 10Q, p.19). Fastow and Kopper managed LJM2. Fastow, through LJM Capital Management, was the general partner and Kopper, through Big Doe, was a limited partner. Kopper had been a managing director who reported to Fastow; in July 2001 he resigned from Enron and purchased Fastow's share. For Kopper and Fastow, the LJM partnerships were highly lucrative: for example, Fastow earned \$30 million. (Enron Form 10Q, p.19)

Enron and LJM2 engaged in a number of transactions. The following is a discussion of hedging activities involving the four Raptors.

\section{Capitalization of the Raptors}

Early in 2000, Enron and LJM2 created Raptor I (Talon). LJM2 contributed \$30 million; Enron contributed $\$ 1,000$, a note for $\$ 50$ million and Enron stock and stock contracts with a market value (at the time) of $\$ 537$ million. $^{8}$ (Powers, p. 100) In exchange Enron received a limited interest in Talon and a note for \$400 million. Enron also agreed to pay $\$ 41$ million to Talon for a put option on 7.2 million shares of Enron stock. ${ }^{9}$ Talon distributed the $\$ 41$ million to LJM2. This distribution was required under an unwritten agreement before Talon could enter into any hedging activities with Enron. As a result, by the time Enron and Talon began hedging activities, the LJM partners had in effect received not only a return on their \$30 million investment, but a return of the investment as well. However, for accounting purposes the investment was still in place, making it possible to treat Talon as an SPE that could be kept off Enron's balance sheet.

\footnotetext{
${ }^{8}$ This was also restricted stock that could not be sold for three years. Therefore it was discounted by $35 \%$.

9 At the time Enron's share price was $\$ 68$. The option was structured that as long as Enron stock did not decline below $\$ 57.50$ a share, it would expire after six months. In fact, the option was settled in August.
} 


\section{LJM2 and The Raptors}

Exhibit 3: LJM2

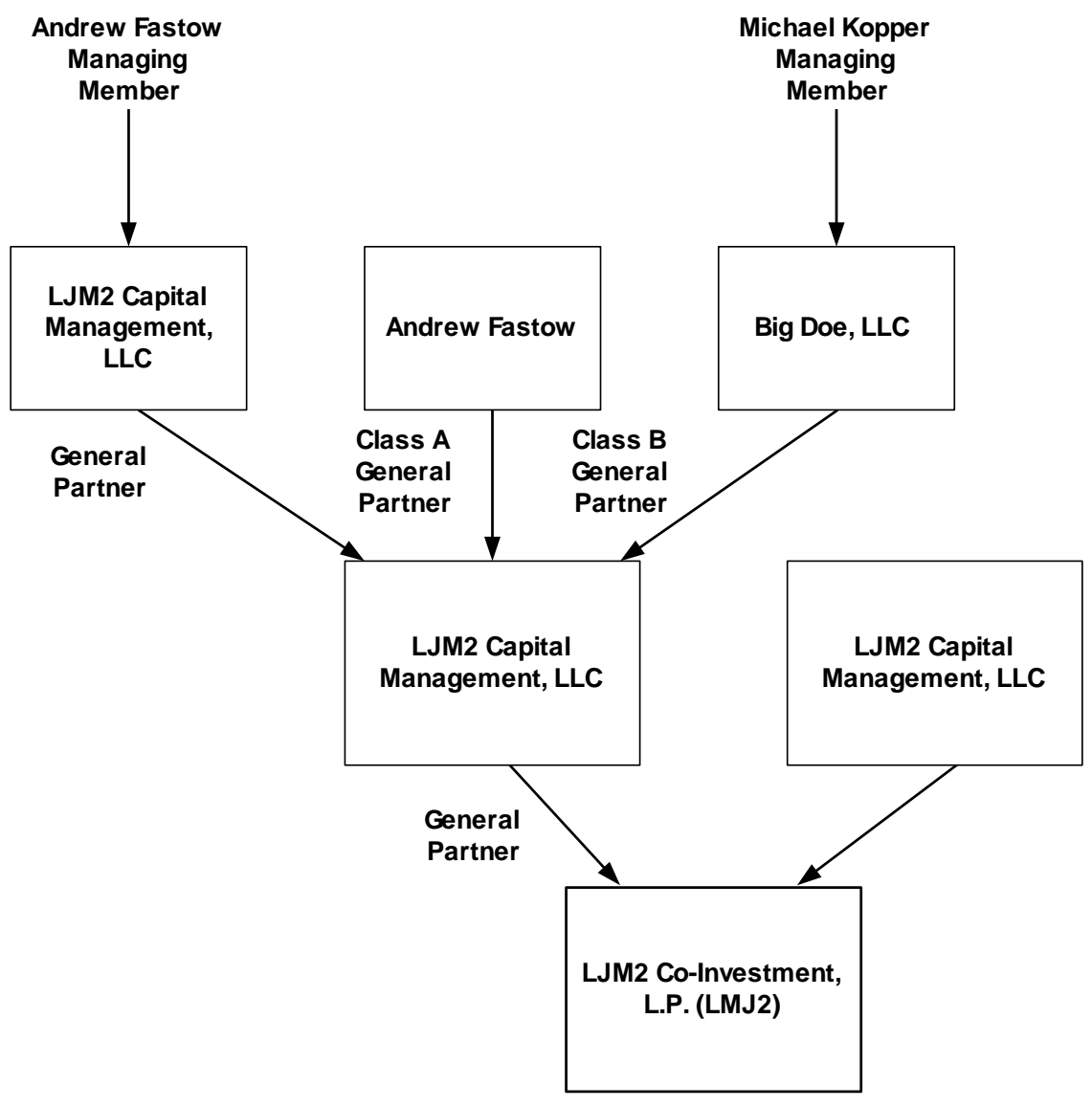

Source: Powers p. 74

Raptors II (Timberwolf) and IV (Bobcat) were essentially structured like Raptor I, capitalized with contingent contracts to receive Enron stock. ${ }^{10}$

Raptor III (Porcupine) was not capitalized with Enron stock, instead Enron contributed shares in an Enron created company, The New Power Company (TNCP) in exchange for a note for \$259 million. Prior to creating Porcupine, Enron had sold a part of TNCP to an SPE (Hawaii 125-0) ${ }^{11}$ formed with an outside investor. In July of 2000, it had also sold warrants for TNCP stock to LJM2 and other investors for a price equivalent to $\$ 10.75$ a share. The price implied in the note receivable from Porcupine was based on this sale, even though Enron knew it would make a public offering of TNCP at a price between \$18 and \$20 one week later. The actual price for the IPO was $\$ 21$ per share, closing at $\$ 27$ on the issue date.

${ }^{10}$ Enron had contributed stock under an agreement that its total value would amount to $\$ 1$ billion. As the market value of Enron shares declined, this required that increasingly larger amounts of stock had to be supplied. Eventually, this proved impossible and contributed to the decision to unwind the raptors.

${ }^{11}$ The name "Hawaii 125-0" was based on the old television show "Hawaii 5-0", with a sly reference to Statement of Financial Accounting Standards 125, according to (Smith (2) 2002) 
Exhibit 4: Raptor I (Talon)

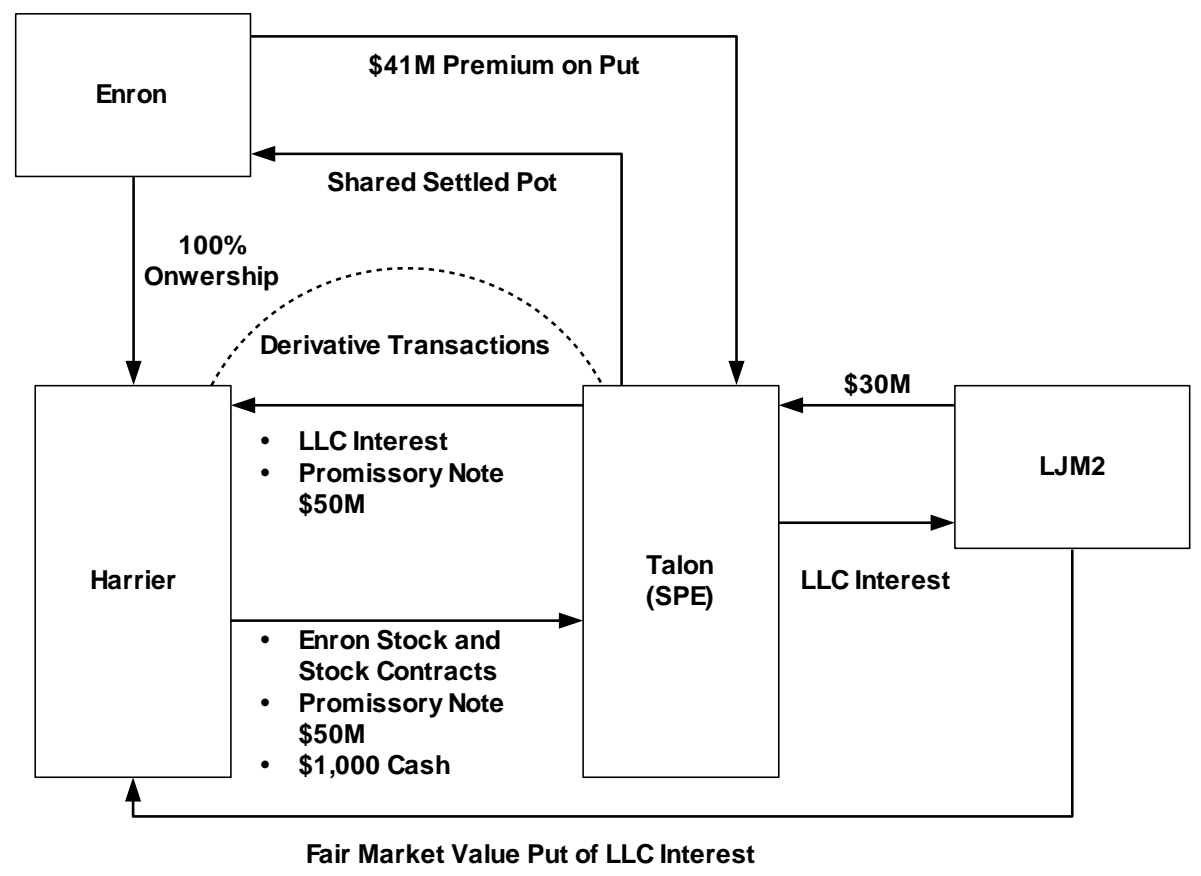

Source: Powers p. 101

As with Raptor I, the outside partners contributed \$30 million to each of the raptors and received $\$ 41$ million from Timberwolf and Bobcat and \$39.5 million from Porcupine, one week after making the investment. The investment in Porcupine generated an internal rate of return of 2500\% for LJM2 (Powers, p.118)

\section{Hedging Activities and Revenue Recognition from the Raptors}

The purpose of the Raptors was to protect Enron's financial statements against fluctuations in the market value of Enron investments that had to be "marked to market". Enron entered into about 20 hedges with the Raptors; by November of 2000 they had a notional value of $\$ 1.5$ billion. As a result, Enron offset losses in its investments of $\$ 500$ million by corresponding gains on the hedges. ${ }^{12}$ Following are two examples:

Talon and Avici: Talon was used to hedge Enron's investment in Avici Systems, Inc. (Avici), an Internet architecture firm. Enron owned a large share of the company's stock and on September 15, 2000 it entered into a total return swap with Talon on Avici stock. At that time Avici traded for about $\$ 95.50$ a share. However, the swap agreement was dated as of August $3^{\text {rd }}$. This was also the day on which Avici stock traded for $\$ 162.50$ per share, its all time high. By September 30 when Avici had dropped to $\$ 95$ a share, Enron offset $\$ 75$ million in losses as a result of the swap. ${ }^{13}$

\footnotetext{
${ }^{12}$ For a detailed description of Enron's transactions with the Raptors see Enron's Form 10Q, pages 22 through 24. A more detailed discussion of selected transactions is provided in the "Powers Report", pages 134 through 147.

${ }^{13}$ On March 27, 2002 Avici traded for \$2.08 a share.
} 
Exhibit 5: Raptor III (Porcupine)

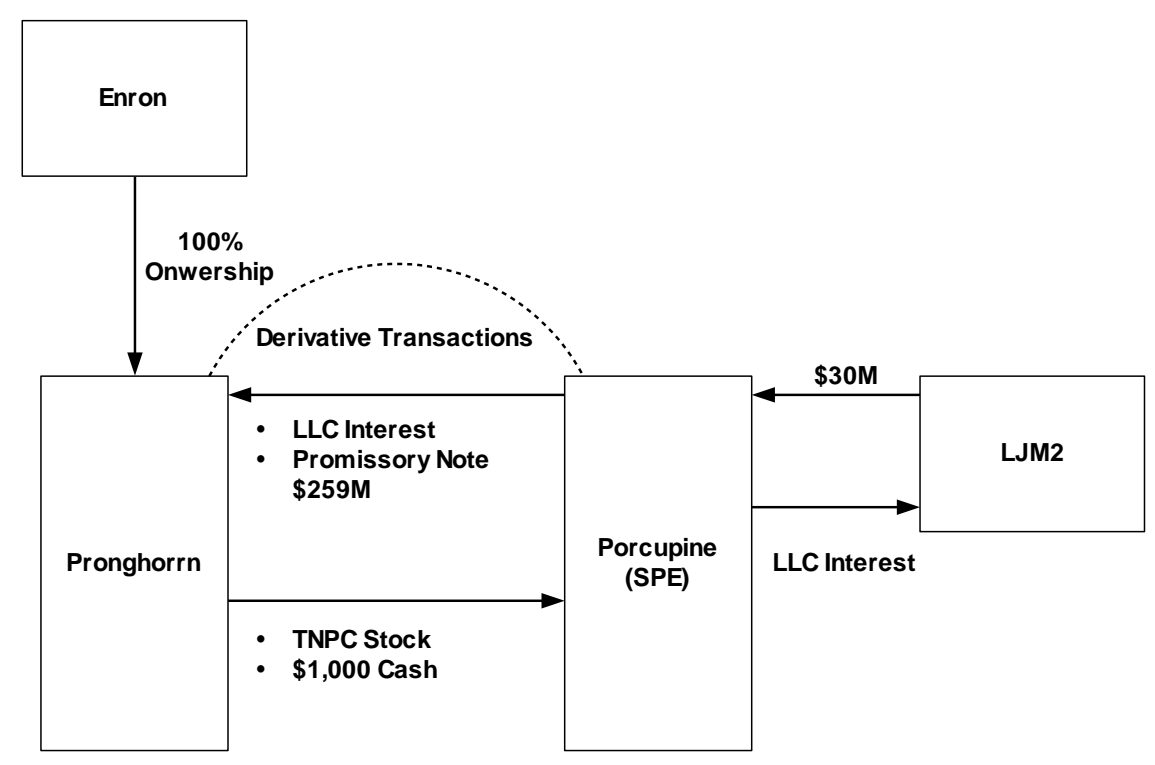

Source: Powers p. 116

Porcupine and TNCP: Enron and Porcupine entered into a total return swap on $\$ 18$ million shares of TNCP stock at \$21 a share. This enabled Enron to lock in a gain on its transactions with Hawaii 125-0 in the amount of $\$ 370$ million.

\section{Problems with the Raptors}

The Raptors were designed to protect Enron's financial statements against losses from declines in the market value of a variety of investments held in its "merchant portfolio". This depended on the credit worthiness of the Raptors. If that became questionable, Enron would have to record credit reserves, negating the positive effects of the hedges. For Talon, Timberwolf, and Bobcat this required that the value of Enron stock (their only asset) increase to offset the significant losses they incurred on most of their derivative transactions with Enron. Porcupine, however, had to rely on the value of its TNCP stock, the same stock it was hedging!

To shore up the credit capacity of the Raptors, Enron took several steps. It restructured them with the effect that in essence the four Raptors were one entity, making it possible to offset losses of one with the "excess" credit capacity of the others. Enron also arranged to provide up to 18 million shares of Enron stock to Raptors II and IV in exchange for notes receivable in the amount of $\$ 260$ million. To ensure the credit capacity of the raptors further, Enron entered into complex hedging arrangements that required it to deliver additional stock, if the price of Enron shares should decline further. Overall, Enron had agreed to deliver up to 30 million shares of Enron stock to the Raptors by 2005 in exchange for notes receivable.

Enron accounted for the various stock issuances to the Raptors by increasing stockholders' equity by $\$ 1$ billion and recording assets (notes receivable) in the same amount.

The Raptors had an enormous impact on Enron's financial position: For the period including the $3^{\text {rd }}$ quarter of 2000 to the $3^{\text {rd }}$ quarter of 2001 , they contributed $\$ 1,077$ million out to the total reported earnings of $\$ 1,508$ million. (Powers, p. 133) At one time the market value of Raptor investments was $\$ 2$ billion. Unfortunately, in the general "new technology" meltdown, the value of these investments and of Enron stock declined significantly. By 
October 2001, Enron decided to liquidate the Raptors, since otherwise it would have had to contribute excessive amounts of stock. The liquidation of the Raptors required payment of $\$ 35$ million to the outside investors and the removal of $\$ 1.2$ billion of assets and equities from Enron's balance sheet. (Enron Form 10Q, p.18)

On November 8, 2001, Enron filed Form 8K with the SEC, announcing the restatement of its financial statement dating back to 1997 and that prior financial statements should not be relied upon.

Included were the following: The removal of $\$ 1.2$ billion of equity and assets from the issuance of stock to the raptors; the reversal of income recognized from Braveheart; $\$ 92$ million in "prior year proposed audit adjustments and reclassifications (which were previously determined to be immaterial in the year originally proposed" (Enron Form 8K, p. 3). It further includes the effects of consolidating Jedi and Chewco, as well as LJM 1 (Enron Form 8K, p 5-7). Finally, it is stated (p.3) that the Powers committee was reviewing the activities and structure of the LJM partnerships and that additional restatements might be required.

\section{Epilogue - Oversight, Culture, And Ethics At Enron}

What was the role of Enron's board of directors in these transactions?

Enron's Board of Directors approved Chief Financial Officer Fastow's participation in the related-party transactions with the understanding that these would be reviewed by both Causey (Chief Accounting Officer) and Buy (Senior Risk Officer). It also "assigned the Audit and Compliance Committee an expanded duty to review the transactions" (Powers, p. 148). Further, the Finance Committee was to review the LJM transactions quarterly and the Compensation and Management Development Committee was to review Fastow's compensation from both Enron and the LJM partnerships. (Powers, p. 155)

Enron's Code of Conduct provided that no full-time officer or employee should "[o]wn an interest in or participate directly or indirectly, in the profits of any other entity which does business with or is a competitor of the Company, unless such ownership or participation has been previously disclosed in writing to the Chairman of the Board and Chief Executive Officer of Enron Corp. and such officer has determined that such interest or participation does not adversely affect the best interests of the Company. (Powers, p. 44)

Since Fastow was a full-time officer of the company legal counsel (in-house and outside) advised that his participation in the SPEs had to be disclosed in Enron's proxy statement. To avoid this, one of his subordinates, Kopper, was designated as the manager of one of the SPEs (Chewco). As an Enron employee, Kopper, too, was required to obtain permission to participate in third-party transactions under the Code of Conduct. There is no written documentation that he did so.

The minutes of the Board appear to be incomplete. Kopper participated in the Executive Committee of the Board's conference call where the Chewco loan was discussed and approved but "the minutes do not reflect any mention of Kopper's personal participation in the Chewco transaction" (Powers, p. 47). Ultimately, Kopper transferred his limited partnership interest in Chewco to his non-Enron connected life partner, Dodson.

According to Powers (p. 10), Causey and Buy, who were supposed to review Fastow's third-party transactions, focused their attention on his activities in a very narrow manner. The Board was not provided complete information nor did the members of the Board appear to seek more. In addition, neither the Compensation Committee nor Enron's Senior Management addressed Fastow's compensation from the partnerships until forced to do so in October 2001 because of media reports. (Powers, p. 11) "Fastow and other Enron employees received tens of millions of dollars they should not have received...at Enron's expense" (Powers, p. 16).

Executive Vice President and Chief Financial Officer Fastow was heavily involved in the transactions that led to Enron's collapse. What about other senior managers at Enron, for example Chairman Lay, President and Chief 
Executive Officer Skilling, Executive Vice President and Chief Accounting Officer Causey, and Senior Risk Officer Buy? At this time there is no answer to the question of "what did they know and when did they know it?"

Concerns were raised by at least three Enron employees prior to the mid-August 2001 then-anonymous memorandum to Chairman Lay. McMahon, the then-Treasurer of Enron alleges that he complained to Skilling of Fastow's conflicts of interest and his feeling that Fastow, McMahon's supervisor, was pressuring him to make deals that were not in the best interests of Enron (Powers, p. 167). Kaminski, head of Enron's Research Group, modeled one of the transactions (the Rhythms/Swap Sub formation) as early as mid-1990. He claims to have reported his concerns to Buy, his supervisor, and to have "strongly recommended to Buy that Enron not proceed with the transaction" (Powers, p. 84) because of Fastow's conflict of interest, the early pay out to LJM1, and the instability of the capitalization. (Powers, p. 84-85) In September 2000, Zisman, an Enron North America attorney, wrote in a memorandum regarding the Raptor structure: "...it might lead one to believe that the financial books at Enron are being "cooked" in order to eliminate a drag on earnings that would otherwise occur under fair value accounting" (Powers, p. 109). Apparently, none of these concerns were taken seriously.

Not until Watkins' mid-August 2001 memorandum to Lay and her subsequent detailed letter and supporting documents presented to him during their one-hour meeting on August 22, were these concerns deemed to be cause for serious alarm. Watkins outlined four areas of potential impropriety -- conflicts of interest, the accounting treatment of Raptor, the adequacy of public disclosures, and the impacts on Enron's financial statements. Lay and Enron's General Counsel, Derrick, requested an investigation by Enron's outside law firm, Vinson \& Elkins. The firm was chosen, despite the fact that Vinson \& Elkins had been party to LJM and Raptor transactions. The investigation did not delve into Andersen's advice or accounting treatment nor did it conduct "a detailed review of individual LJM transactions" (Powers, p. 173). Furthermore, it concluded that no major corrective actions were required.

The abrupt resignation of Jeffrey Skilling in August 2001 raised concerns within and outside the company. In response senior management, specifically Lay, went on-line for a question and answer session with employees on September 26, 2001, more than a month after Watkins' disclosures, and told employees to "talk up the stock and talk positively about Enron to your family and friends...[T]he company is fundamentally sound. The balance sheet is strong. Our financial liquidity has never been stronger"(New York Times, 2002, p. B5). This September communication was sent after Lay, himself, within days of receiving Watkins' memorandum, allegedly disposed of significant amounts of Enron stock (New York Times, 2002, p. B1)

The rise and collapse of Enron raise many questions. Was it a visionary and innovative company destroyed by unforeseeable market forces as claimed by its management? Or, as charged by critics, was it merely a house of cards that could only flourish in the overheated "New Economy" mania of recent years? What occurred at Enron has been described as "a wholesale systemic failure. The multi-layered system of checks and balances that is supposed to keep a company from running amok completely broke down." (Sloan, 2002, p. 19) Although answers to many of these questions are still lacking, it is clear already that Enron will impact many areas. Financial reporting and disclosure and the rule making process, both in the U.S. and internationally, are being questioned. The accounting and auditing profession is under attack. The role of financial analysts and investment banking is under intense scrutiny and demands are made for reform of corporate boards of directors. Only time will tell, how many of the reforms demanded at this time will actually occur, however, it is already certain that Enron will occupy a special niche in U.S. business history.

\section{Questions:}

1. Examine Enron's revenue recognition practices from its various partnerships. Explain why these practices were (were not) appropriate.

2. Special Purpose Entities (SPEs) played an important part in Enron's success and ultimate failure. Describe the purpose of SPEs, the requirements that must be met to keep SPEs "off the balance sheet" and explain why ultimately Enron had to consolidate the SPEs discussed in the case.

3. Explain why Enron had to remove $\$ 1$ billion in equity from its balance sheet (stock issued to the Raptors). 
4. An important purpose of the Raptors was to hedge investments included in Enron's "merchant portfolio". Examine and explain the following:

a. Why investments in the "merchant portfolio" are subject to "mark to market" accounting rules and the effects of "mark to market" on the income statement.

b. Why companies may wish to reduce these effects.

c. How derivatives can be used to accomplish this goal.

5. "Related party transactions" are an important factor in the Enron case. Explain the following:

a. What are considered related party transactions and the financial reporting rules that govern their disclosure. Why do these requirements exist?

b. What were the related party transactions in this case? Were they properly disclosed?

c. What was their ultimate effect on Enron?

6. Despite having a statement concerning 'Our Values' and having a 'Code of Conduct,' Enron has been described as a "wholesale systemic failure." What should the Board of Directors; its various subcommittees, and those in the management hierarchy have been done, to prevent this failure from occurring?

Rest assured that business ethics exists. But, like all ethics, it is under fire. Because it exists in the sphere of aspiration, where one's reach exceeds one's grasp, it is condemned to play the role of the critic. It lives in the gap between what is and what ought to be. To create awareness of this breach is to create discomfort. (Litzinger, et. al, p. 21)

7. There were at least four such critics at Enron -- McMahon, Kaminski, Zisman, and finally Watkins. How did the culture and leadership at Enron influence employees' and Management's' (un)ethical behavior? What actions/activities would you recommend to create an atmosphere where business ethics were taken seriously?

\section{References:}

1. AccountancyMagazine.Com, “Enron Collapse Has Silver Lining for IASB”, Dec. 20, 2001: http://www.smartpros.com/x32215.xml

2. $\quad$ Eichenwald, Kurt and Henriques, Diana B., "Web of Details did Enron in as Warnings Went Unheeded"; The New York Times online, February 10, 2002: http://www.nytimes.com/2002/02/10/business/10COLL.html?pagewanted=4\&ei=5

3. Elliott, Bob in CSPAN interview, January 10, 2002

4. $\quad$ Enron Corporation, Form $10 \mathrm{~K}$ for the fiscal year ended December 31, 2000: http://www.sec.gov/Archives/edgar/data/

5. $\quad$ Enron Corporation, Form $10 \mathrm{Q}$ for the quarter ended September 31, 2001: http://www.sec.gov/Archives/edgar/data/

6. Enron Corporation, Form 8 K. November 8, 2001: http://www.sec.gov/Archives/edgar/data/

7. Hilzenrath, David S., "Early Warnings of Trouble at Enron", The Washington Post, December 30, 2001: http://www.washingtonpost.com/ac2/wp-dyn?pagename=article\&node=\&contentId=A40094-2001Dec29

8. Litzinger, W. D. and Schaefer T. E., "Business Ethics Bogeyman: The Perpetual Paradox," Business Horizons, March-April 1987, p. 21.

9. Los Angeles Times, "Enron Debacle Shakes Up Congress' Agenda; War Now Shares Spotlight”, January 27, 2001, p. 1

10. McKinnon, John D. and Hitt, G. "Double Play How Treasury Lost In Battle to Quash a Dubious Security", The Wall Street Journal, February 4, 2002, pages A1, A8.

11. New York Times, "Enron Chief Went Online to Urge Stock Purchase", January 19, 2002, p. B1, B 5.

12. Powers, William Jr.: "Report of Investigation by the Special Investigative Committee of the Board of Directors of Enron Corp." Enron Corp., February 4, 2002: http://public.wsj.com/enronreport020202.pdf Or: http://news.findlaw.com/wp/docs/enron/specinv020102rpt1.pdf http://news.findlaw.com/wp/docs/enron/specinv020102rpt2.pdf 
http://news.findlaw.com/wp/docs/enron/specinv020102rpt3.pdf

http://news.findlaw.com/wp/docs/enron/specinv020102rpt4.pdf

13. Sloan, Allan. "Digging into the Deal That Broke Enron". Newsweek, December 17, 2001, pp. 48-50.

14. “Who Killed Enron". Newsweek January 21, 2002, p. 19.

15. Smith, Rebecca. "Blockbuster Deal Shows Enron's Inclination to All-Show, Little Substance Partnerships", The Wall Street Journal January 17, 2002, online: http://online.wsj.com/article_print/0,4287,SB1011217368129907240,00.html

16. . "Short Circuit How Enron's Plan to Market Electricity Nationwide Fizzled", The Wall Street Journal March 25, 2002 p. 1.

17. _ and Emshwiller, John R., "Enron Replaces Its Finance Chief --- Stock Recovers Slightly After

18. Washington Post Special Report on Enron:

http://www.washingtonpost.com/wp-dyn/business/specials/energy/enron/

Notes 
Notes 